\title{
THE CREATIVE WORK OF ARCHITECTOR PIERRE RICAUD DE TIRREGAILLE
}

\author{
ТВОРЧИЙ ДОРОБОК АРХІТЕКТОРА П'ЄРА РІКО ДЕ ТІРРЕГАЙЛЯ
}

\author{
(C) Tapac B., 2020
}

Незважаючи на те, щио постать цього військового інженера, геометра, архітектора П'єра Ріко де Tірретайля (Tірргайль, фр. Pierre Ricaud de Tirregaille, Ricaud (Ricaut, Ryko) Pierre de Tirregaille (Tirgaille)) (близько 1725 - niсля 1772) є порівняно добре знайома дослідникам, його біографія, поза періодом діяльності у Речі Посполитій, залишасться ще великою мірою не відома. Узагальнення та систематизація результатів попередніх досліджень показали, щчо наукові розвідки щцодо заданої теми провадили в декількох напрямках. До першого напрямку належать такі дослідження авторів, які присвячено особистості архітектора П'сра Ріко де Тірретайля та які умовно можна поділити на праці, щц стосуються біографічних відомостей про архітектора, $i$ студї про різноманітні проекти, які П'єр Ріко де Тірретайль виконав на замовлення. Важсливими джерелами для з'ясування бібліографічних відомостей про П'єра Ріко де Тіррегайля та здійснених із його боку проектних замовлень с рукописні й графічні матеріали, які зберігаються в архівах Варшави, Кракова, у Національному інституті спадщини в Варщаві та в Національній бібліотеці Франції в Парижі.

Ключові слова: архітектор, П'ср Ріко де Тіррегайль, палац, сад.

\section{Постановка проблеми}

Мистецтвознавчі та історико-архітектурні студії про життя і творчість архітектора П'єра Ріко де Тіррегайля є вибірковими та неповними. Щодо його діяльності зберіглося мало відомостей, більшість документів та креслень розпорошено по архівних фондах різних країн, деякі з них не мають підпису автора. Аналіз архівних матеріалів та наукових публікацій дав можливість показати різноманітність творчості архітектора.

\section{Мета статті}

Висвітлити життєвий та творчий шлях архітектора П'єра Ріко де Тіррегайля.

\section{Аналіз останніх досліджень та публікацій}

Узагальнення та систематизація результатів попередніх досліджень показали, що наукові розвідки щодо заданої теми провадили в декількох напрямках. До першого напрямку належать такі дослідження авторів, які присвячено особистості архітектора П'єра Ріко де Тіррегайля та які умовно можна поділити на праці, що стосуються біографічних відомостей 
про архітектора, і студії про різноманітні проекти, які П'єр Ріко де Тіррегайль виконав на замовлення.

Деякі біографічні відомості про П'єра Ріко де Тіррегайля можна почерпнути 3 бібліографічного видання «Словник польських архітекторів та будівельників, а також іноземців, які працюють у Польщі», яке уклав Станіслав Лоза (1888-1956) (Łoza, 1931, S. 286.) у 1917 р., із «Загальної енциклопедії образотворчого мистецтва від античності до сучасності», яку започаткували Ульріх Тіме й Фелікс Бекер (Begründet, von und Becker, 1938), із «Польського біографічного словника» (1988-1989) (Kowalczyk, 1988-1989, S.270272). Меценатській діяльності коронного гетьмана Яна Клемента Браницького щодо митців, серед яких був й архітектор П'єр Ріко де Тіррегайль, присвячено докторську дисертацію Е. Жилько (Żyłko, 1955). Дослідження М. Морельовського (Morelowski, 1959, S.351), 3. Хорнунга (Hornung, 1959, S.276-284]) акцентують увагу на французькому походженні митця. У розвідці С. Ковальчика (Kowalczyk, 1988, S.299-317; 1981, S.99-114) висвітлено архітектурну діяльність П'єра Ріко де Тіррегайля у Варшаві. Як укладачеві карти Варшави 1762 р. П'єрові Ріко де Тіррегайлю присвячено статті в «Зальній енциклопедіï» (Ricaud de Tirregaille, P., 1867, S.297-298), а також розвідки Б. Ольшевича (Olszewicz, 1932, S.205-206), Є. Ковальчика (Kowalczyk , 1977, S.53-59) та Д. Косачки (Kosacka, 1970, S.29, 54-55).

До другого напрямку досліджень належать праці Т. Маньковського (Mańkowski, 1932, S.110-113; 1948, S.391-433), Є. Ковальчика (1991, С.51,55,62), Е. Свейковського, Я. Чернецького (Czernecki, 1939, S.42-52, 413-429), Я. Pocca (Ross, 1970, S.42-52, 413-429), Г. Гриник, О. Ярош-Замойської (2000), які стосуються питань краєзнавства й історії архітектури та в яких зосереджено увагу на особистості замовника й на архітектурнопланувальному рішенні споруд, які запроектував та побудував П'єр Ріко де Тіррегайль.

Окремий напрямок досліджень становлять роботи зі садово-паркового мистецтва Г. Цьолека (Ciołek i Plapis, 1968; Ciołek, 1954; 1955, S.96-102), Я. Богдановського (Bogdanowski, 2000; S.61, 64, 77, 84, 258), Л. Майдецького (Majdecki, 2008, S.61, 64, 77, 84, 258), у яких П'єр Ріко де Тіррегайль постає як фахівець із проектування та закладення садів.

Важливими джерелами для з'ясування бібліографічних відомостей про П'єра Ріко де Тіррегайля та здійснених із його боку проектних замовлень є рукописні й графічні матеріали, які зберігаються в архівах Варшави (Archiwum Główne Akt Dawnych w Warszawie; Archiwum Roskie, 1757), Кракова (Archiwum Narodowe w Krakowie), у Національному інституті спадщини в Варшаві (Narodowy Instytut Dziedzictwa w Warszawie) та в Національній бібліотеці Франції в Парижі.

\section{Виклад основного матеріалу}

Незважаючи на те, що постать цього військового інженера, геометра, архітектора П'єра Ріко де Тіррегайля (Тірргайль, фр. Pierre Ricaud de Tirregaille, Ricaud (Ricaut, Ryko) Pierre de Tirregaille (Tirgaille)) (близько 1725 - після 1772) є порівняно добре знайома дослідникам, його біографія, поза періодом діяльності у Речі Посполитій, залишається ще великою мірою не відома.

П'єр Ріко де Тіррегайль народився близько 1725 року у французькій дворянській сім'ї у місцевості Тіррегайль у Провансі, де його батьки мали власність. Відомо, що деякий час він мандрував Свропою. Зі збереженої кореспонденції дізнаємося, що перед прибуттям до Речі Посполитої він перебував деякий час в Іспанії (Archiwum Główne Akt Dawnych w Warszawie, S. 553; Archiwum Roskie, 1757), де вдосконалював свою професійну освіту в Барселоні під керівництвом свого родича, інженера Френсіса Рікода де Тіррегайля. 
Польський дослідник Є. Ковальчик у дванадцятирічній діяльності П'єра Ріко де Тіррегайля у Речі Посполитій відокремив три періоди: I - варшавський (1752-1757), II - львівський (1757-1760) і III - варшавський (1760-1762). Більшість доручень, які архітектор отримував під час своєї діяльності у Речі Посполитій, надходило від декількох магнатських родів: Браницьких, Потоцьких, Мнішів та ін.

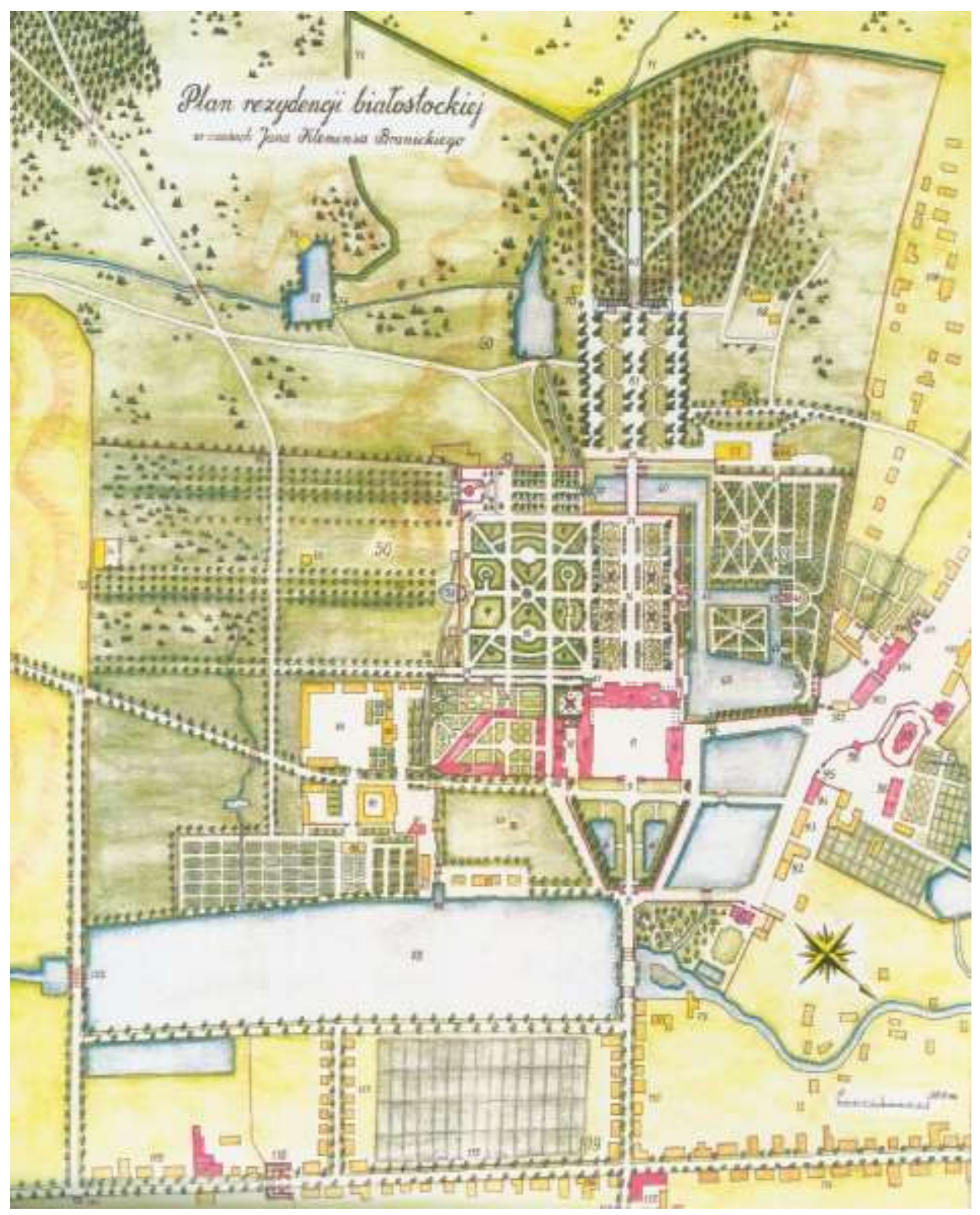

Рис. 1. м. Білосток. План резидениії гетьмана Браницьккого.

Перша згадка про перебування П'єра Ріко де Тіррегайля у Речі Посполитій походить із 1752 року, коли він отримує звання поручника в піхотному полку великого коронного гетьмана Яна Климента Браницького (1689-1771) і як військовий інженер заступає на службу (Narodowy Instytut Dziedzictwa w Warszawie, Teka 321. - S. 26). У 1753 р. його чин підвищують до капітана, 11 жовтня1753 р. у Варшаві він одружується з Барбарою Цецевич (Cieciewiczówna) (Narodowy Instytut Dziedzictwa w Warszawie, Teka 320. - S. 162. - 1753 r), дочкою Антоні, міського письменника Старої Варшави, згодом у сім'ї народжується троє дітей. Окрім військової зарплатні, П'єр Ріко де Тіррегайль отримує фіксовану зарплатню в 200 дукатів на рік від гетьмана Яна Браницького, який наймає його на роботу інженером у 
свою резиденцію в Білостоку упродовж 1753-1757 pp.. Однак П'єр Ріко де Тіррегайль не переїжджає до Білостока, а залишається у Варшаві, де також отримує інші замовлення. Упродовж чотирьох років він відвідує резиденцію в Білостоку лише у весняно-літній сезон, йому було доручено розробку та керування монтажними роботами з водопостачання саду й звіринцю за допомогою гідравлічних пристроїв, які мали забезпечити водою фонтани, каскади, канали та ставки (Рис. 1) (Narodowy Instytut Dziedzictwa w Warszawie, Teka 320. - S. S. 1-2; Teka 353. - S. 1; Teka 358. - S. 25, 29, 33, 38, 39).

Два роки поспіль (1752-1754) П'єр Ріко де Тіррегайль навчає учня, сина Каспера Дюшені (Duchesne), імовірно, архітектора французького походження, та складає йому протеже у Браницького в Білостоку (Narodowy Instytut Dziedzictwa w Warszawie, S. 176. 1754 r.). Гетьман Браницький називав П'єра Ріко де Тірpегайля «мій інженер» (Narodowy Instytut Dziedzictwa w Warszawie, S. 142a, 143, 159-162, 176, 208, 214, 216, 217, 220, 221), очевидно, що він також допомагав гетьманові своїми архітектурними та дизайнерськими знаннями, принаймні порадами. Архітектор піддав критиці основні задуми гетьманських митців у резиденції в Білостоку, що, безумовно, послужило джерелом конфлікту між П'єром Ріком де Тіррегайлем і головним архітектором гетьмана Браницького полковником Яном Генріком Клеммом. У 1754 р. Тіррегайль зіштовхується з «надуманим» конфліктом щодо термінів завершення робіт із прокладення водяних закладень у садах Білостока (Narodowy Instytut Dziedzictwa w Warszawie, Teka 341. - P. 8. - 1754 r.. За словами Ю. Курдвановського (Kurdwanowski), у розмові з П'єром Ріко де Тіррегайлем він намагався заохотити його швидше завершити роботи, але в нього залишилися сумніви щодо запевнень інженера (Narodowy Instytut Dziedzictwa w Warszawie, Teka 341. - P. 8. - 1754 r.). Така ситуація викликала незадоволення гетьмана Браницького, відтак роботи, якими мав керувати П'єр Ріко де Тіррегайль, переходять до іншого архітектора Петера Лоренса (Lorenz Peter Christoph), а гетьман висловлює свою готовність особисто контролювати прокладення труб (Narodowy Instytut Dziedzictwa w Warszawie, Teka 342. - S. 35, 38, 40, 41). Свою зарплатню від Браницького П'єр Ріко де Тіррегайль отримує дорогою з Варшави до Білостока (Narodowy Instytut Dziedzictwa w Warszawie, Teka 315. - S. 317). Уже у 1755 p. (Narodowy Instytut Dziedzictwa w Warszawie, Teka 320. - S. 222) i 1756 р. П'єр Ріко де Тіррегайль їде до Білостока власним коштом (Narodowy Instytut Dziedzictwa w Warszawie, Teka 320. - S. 235). У 1757 p. він одержує лист із грішми від підполковника Клемма, за що дякує йому у зворотному листі від свого імені і від імені дружини (Narodowy Instytut Dziedzictwa w Warszawie, Teka 315. S. 251). Це була остання платня. У зв'язку з припиненням виплат П'єр Ріко де Тіррегайль звертається до Браницького, нагадуючи йому про раніше надану обіцянку виплачувати йому гроші, зважаючи на сімейні обставини, до того часу, поки він не знайде іншої відповідної роботи (Narodowy Instytut Dziedzictwa w Warszawie, Teka 353. - S. 1). У відповідь гетьман Браницький наказує виплатити останню зарплатню не особисто П'єрові Ріко де Тіррегайлю, а його кредиторові, полковнику Гіршу (Hiche) (Narodowy Instytut Dziedzictwa w Warszawie, Teka 315. - S. 248. - 1758 r.). На початку 1758 р. П'єра Ріко де Тіррегайля було звільнено зі служби в Браницького. Ян Генрік Клемм скаржиться, що після звільнення П'єра Ріко де Тіррегайля він позбавлений «Астролябії», книги з архітектури та проектів, серед яких плани палацу й саду в Хороші і численні малюнки, які він запозичив у бібліотеці гетьмана Браницького (Narodowy Instytut Dziedzictwa w Warszawie, Teka 339. - S. 11, 12. - 1758 r.).

У 1757 році П'єр Ріко де Тіррегайль переїжджає на чотири роки з Варшави до Львова, де виконує кілька архітектурних проектів. Спочатку для Францішека Салезія Потоцького, воєводи київського, проектує й реалізовує в 1757-1760 pр. великий палацовий комплекс із 
садом у Кристинополі на річці Буг біля Сокаля. Не виключено, що його авторству належить також проект палацу Потоцьких у Переспі 1758 р. (не зберігся). Так, мистецтвознавець В. Вуйцик вважав його автором такого проекту (Вуйцик, 2003, С.68), тоді як польський дослідник Є. Ковальчик лише припускав таку можливість (Kowalczyk, 1988-1989, S.270272). Під час нагляду за роботою в Кристинополі П'єр Ріко де Тіррегайль береться за проект палацу Чацького-Фелінського на Галицькому передмісті Львова за Єзуїтською хвірткою. Згідно з укладеним договором від 13 вересня 1758 р. П'єр Тіррегайль повинен був працювати два роки за 10 тисяч польських злотих. У межах цього проекту архітектор виступив не тільки як проектант, але і як будівельний підприємець, але за два роки йому вдалося закласти лише фундамент, тому 29 серпня 1759 р. Чацький подав на нього скаргу до Львівського міського суду. Близько 1759 р. П'єр Тіррегайль розробив проект модернізації двоповерхового палацу для надвірного ловчого Антонія Бєльського у Львові біля Галицьких воріт (Kowalczyk, 19881989, S. 271), два креслення проектів фасадів зберігаються в Національний бібліотеці в Парижі (Bibliothèque nationale de France).

У Львові П'єр Ріко де Тіррегайль був радником із питань будівництва грекокатолицького митрополита Львова Леона Шептицького, якому в цей час королівський архітектор Б. Меретин завершував будівництво спроектованого собору Святого Юри. Залишаючись прихильником рококо і класицизму, П'єр Ріко де Тіррегайль розкритикував цю споруду, потрактувавши стиль церкви св. Юрія як застарілий. У відповідь на критику Б. Меретин 3 листопада 1758 р. подав позов на архітектора до суду за те, що той, мовляв, висунув невмотивовані обвинувачення. Така критика викликала незадоволення митрополита Льва Шептицького, як наслідок - він розриває договір із П'єром Ріко де Тіррегайлем та припиняє користуватися його послугами, адже на будівництво було зібрано й витрачено значні кошти (Mańkowski, 1932, S.209). Володимир Вуйцик припускав, що автором первинного проекту палацу греко-католицьких митрополитів у Львові також міг бути П'єр Ріко де Тіррегайль, а не Клеменс Фесінгер (Вуйцик, 2003, С.68).

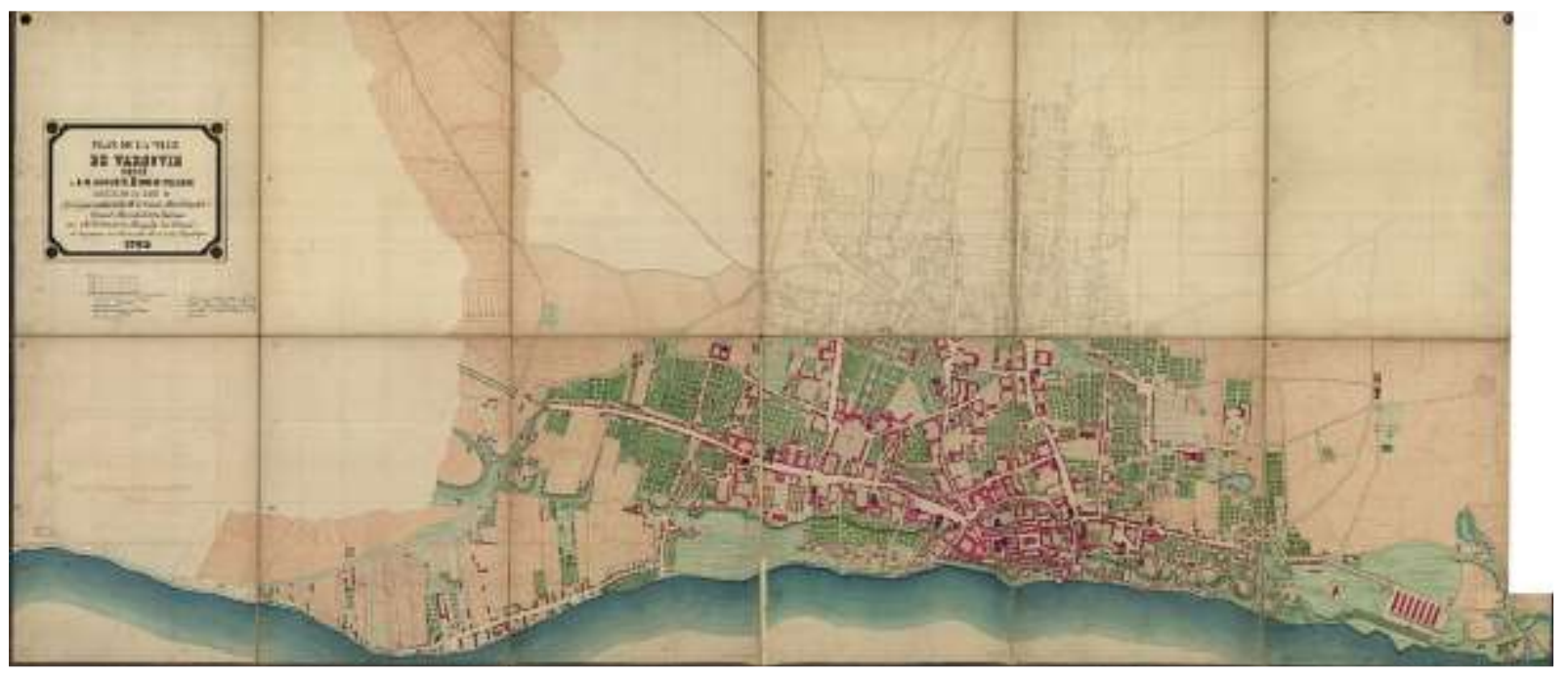

Рис. 2 План Варшави складений архітектором П'єр Ріко де Тіррегайль. 1761 p.

Імовірно, що під час нагляду за будівництвом палацу в Кристинополі П'єра Ріко де Тіррегайля представили Ігнатієві Цетнеру (1728-1806), який неодноразово відвідував палац, позаяк його дружина походила з родини Потоцьких. Наслідком цього знайомства стало запрошення розробити проект палацу в м. Краківці. План палацу, який зберігається в 
Національній бібліотеці Франції в Парижі [8], виконав, за припущеннями Р. Афтаназі (Aftanazy, 1996, S.53-63) та П. Вутроба (Wątroba, 2016, S.67-73), саме П'єр Ріко де Тіррегайль. Авторка цієї статті також вважає, що бароковий сад при палаці в м. Краковець належить авторству П'єра Ріко де Тіррегайля (Kriegsarchiv des Österreichischen Staatsarchivs in Wien., 1763-1787).

На початку 1760 р. коронний гетьман Браницький доручає П'єрові Ріко де Тіррегайлю відмалювати зерновий млин оо. Бернардинів, що рухався за допомогою тяглової сили волів, та керувати теслярем, який мав виконати макет цього млина, який потрібно було відправити в м. Мостиська. Окрім того, гетьман Браницький звернувся до нього 3 проханням спроектувати млин для саду як місця для прогулянок. П'єр Ріко де Тіррегайль надає гетьманові зразки схожих млинів, на які він натрапляв в Іспанії (Narodowy Instytut Dziedzictwa w Warszawie, Teka 315. - S. 164, 209, 210).

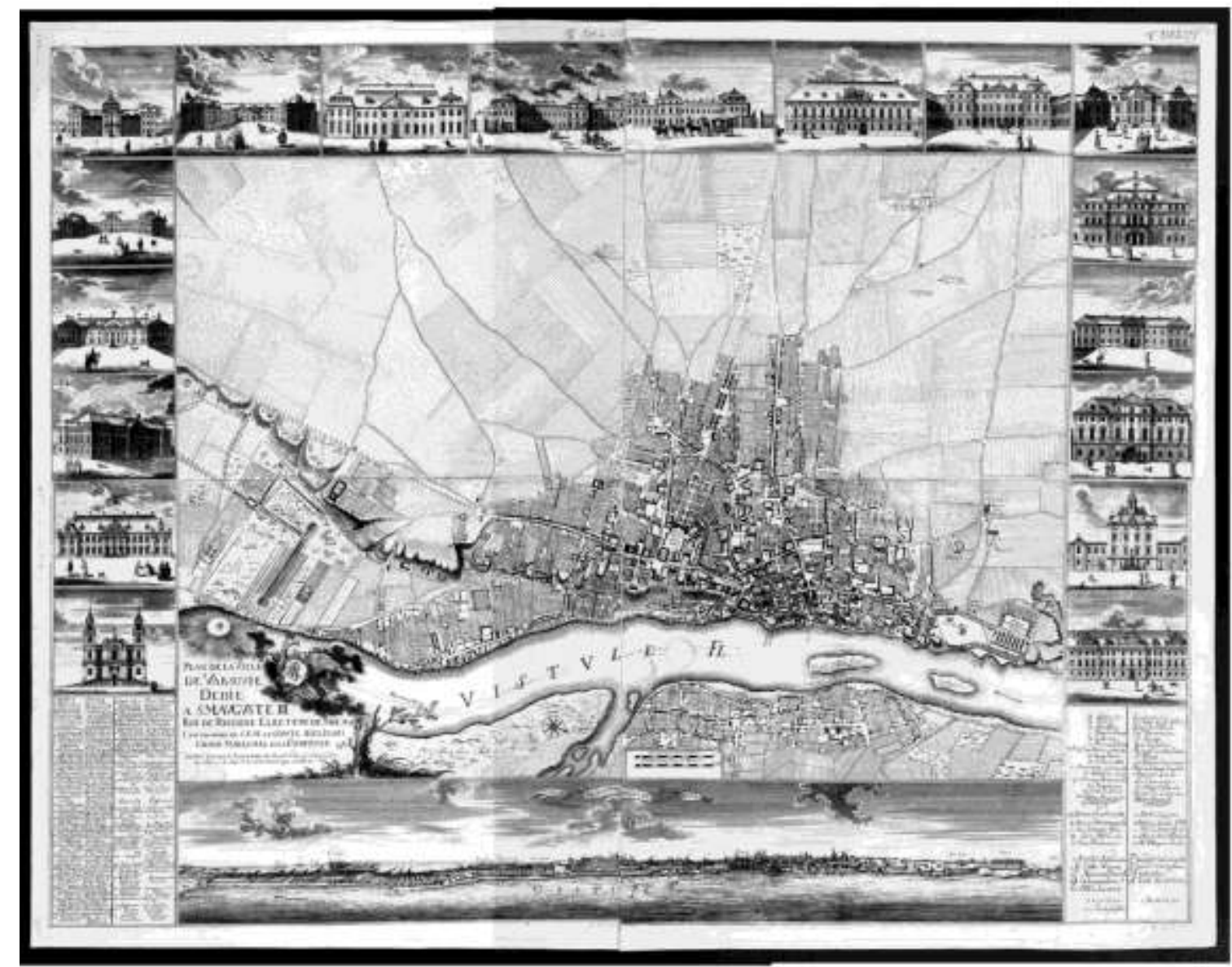

Pис. 3. План Вариави, автор П'єр Ріко де Tірретайль. «Plan de la Ville de Varsovie Dedie a S.M. Auguste III Roi de Pologne Electeur de Saxe. \& \&. Leve par ordre de S.E.M. Comte Bielinski Grand Marcchal de la Couronne par M.P. Ricaud de Tirregaille Lieut Colonel et Inginieur au Service du Roi et de la Republique en 1762».

У кінці 1760 р. П'єр Ріко де Тіррегайль із родиною повертається до Варшави. На прохання коронного маршала Чехії Франциска Бєлінського, який очолював Дорожню комісію (Komisja Brukowa), засновану королем Августом III, він береться за амбіційне завдання - скласти детальний план міста Варшави, яке принесло йому зрештою славу й знаменитість. На вісімнадцяти частинах у масштабі близько 1:1000 він складає план Варшави з передмістями; ймовірно, основою для нього слугували виміри архітектора Якуба Фонтана (Рис. 2). Роботу над планом П'єр Ріко де Тіррегайль завершив 1 травня 1761 р., отримавши винагороду в розмірі 2,533 зл. 10 гр. На прохання Ф. Бєлінського П'єр Ріко де 
Тіррегайль готує план Варшави до друку, зменшуючи його до масштабу 1:6690. Під планом архітектор розміщує панораму міста Варшави зі сторони річки Вісли, зверху та із двох сторін - сімнадцять значних будівель, головним чином палаців - королівських і сенаторських. Після Другої світової війни ці зображення стали цінним джерелом для реконструкції палаців.

Як власникові графічного плану П'єрові Ріко де Тіррегайлю належало й друкарське кліше, яке виконав у 1762 р. на чотирьох мідних пластинах Якуб Теофіл Марстальський (Jakub Teofil Marstalski (Marstaller)). Розроблений план Варшави П'єр Ріко де Тіррегайль збирається присвятити королеві Августу III. Він пропонує гетьманові Браницькому купити в нього кліше (Narodowy Instytut Dziedzictwa w Warszawie, Teka 353. - S. 2, 3). План було опубліковано у 1762 р. під назвою «Plan de la Ville de Varsovie Dedie a S.M. Auguste III Roi de Pologne Electeur de Saxe. \& \&. Leve par ordre de S.E.M. Comte Bielinski Grand Marcchal de la Couronne par M.P. Ricaud de Tirregaille Lieut Colonel et Inginieur au Service du Roi et de la Republique en 1762» (Рис. 3). Імовірно, що, окрім плану Варшави, П'єр Ріко де Тіррегайль планував випустити альбом із тогочасними важливими столичними спорудами, у Національній бібліотеці в Парижі зберігаються його малюнки вул. Краківське Передмістя i палацу Красінських (Bibliothèque nationale de France. Département des estampes et de la photographie) у Варшаві з відповідними топографічними та історичними поясненнями.

Після дев'яти років служби П'єр Ріко де Тіррегайль сподівався отримати підвищення, ще в грудні 1761 р. він звернувся з проханням до гетьмана Браницького посприяти йому у справі просуванні до чину полковника; це прохання також підтримав i маршал Ф. Бєлінський, який зі свого боку просив гетьмана допомогти в королівському дворі цьому призначенню, яке «надасть плану Варшави більшого значення» (Narodowy Instytut Dziedzictwa w Warszawie, Teka 325. - S. 226. - 1761 r.), але, на жаль, цього не сталось. Після одинадцятирічного перебування в Польщі П'єр Ріко де Тіррегайль, не маючи можливості обійняти відповідної посади при дворі Августа III, між 1762-1763рp. переїжджає до Берліна, де його при дворі прусського короля Фрідріха II зараховують до інженерного корпусу на невизначену посаду та посаду викладача. У 1765 р. у Потсдамі Ріко де Тіррегайль одружується з Марією-Луїзою Бініус (Marią Louisą Binius).
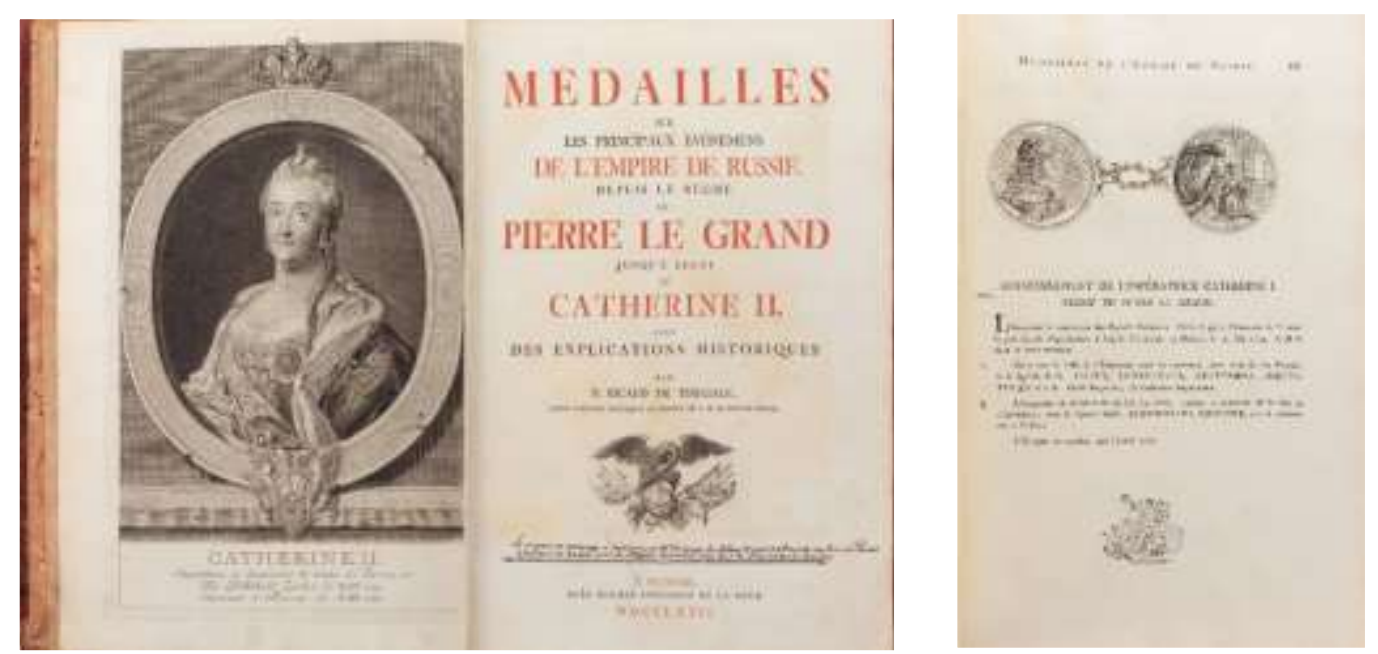

Puc. 4. Нумізматичний трактат «Médailles sur les principaux événements de l'Empire de Russie, depuis le règne de Pierre le Grand jusqu'à celui de Catherine II. Avec des explications historiques. A Postdam, chés Sommer, 1772» виданий П'єром Ріко де Тіррегайлем.

П'єр Ріко де Тіррегайль продовжує підтримував контакти з Польщею, у 1765 р. він звертається з листом до Ізабелли Браницької з проханням посприяти у справі купівлі королем 
Станіславом Августом вісімдесяти картин «найдавніших і найвідоміших художників» у венеціанського барона Де Бодіссона (Bodissony) (Narodowy Instytut Dziedzictwa w Warszawie, Teka 315. - S. 291, 292). Ця угода відбулась, і цього ж року в Берліні архітектор отримує гроші від гетьмана Браницького за посередництво в цій справі (Narodowy Instytut Dziedzictwa w Warszawie, Teka 315. - S. 323).

У 1772 р. в Потсдамі він видає нумізматичний трактат, присвячений російським медалям XVIII ст. Ця ілюстрована праця під назвою: «Médailles sur les principaux événements de l'Empire de Russie, depuis le règne de Pierre le Grand jusqu'à celui de Catherine II. Avec des explications historiques. A Postdam, chés Sommer, 1772» складалась зі ста одинадцяти вигравіюваних віньєток із двостороннім зображенням та історичними поясненнями російських медалей, викарбуваних із часів Петра I до Катерини II включно (Рис. 4). У 1776 p. П'єр Ріко де Тіррегайль отримує чин полковника та продовжує працювати над наступним томом нумізматичного трактату, присвяченого медалям Бранденбурзького двору, але невдовзі він помирає.

\section{Використана література та джерела:}

Вуйцик, В. С., 2003. Львівські барокові палаци. Палац Більських. Вісник інституту «Крзахідпроектреставрація», 13.

Гриник, Г. та Ярош-Замойська, О., 2000. Кристинопіль (1692-1951). Червоноград.

Ковальчик, Є., 1991. Пізньобарокові магнатські резиденції на Волині та Львівщині. Украӥнське бароко та європейський контекст. Київ : Наукова думка.

Aftanazy, R., 1996. Dzieje rezydencji na dawnych kresach Rzeczypospolitej. Vol. 8: Wojewodztwo ruskie: Ziemia Przemyska i Sanocka. Wrocław.

Archiwum Główne Akt Dawnych w Warszawie. Sigillata 27.

Archiwum Narodowe w Krakowie. Plan pałacu Franciszka Salezego Potockiego wojewody kijowskiego w Krystynopolu oraz pałacyku w Perespie. Archiwum Potockich w Krzeszowic. - Sign. 3137. 29/635/0/14/3137.

Archiwum Roskie, 1757. Sygn. XVIII/34 (6 листів Р. Тіррегайля до Я. Браніџьького від l. 1752-62), sygn. ХХХIV/29 (лист Р. Тіррегайля до Я. Клемма від 1757).

Begründet, von U. T. und Becker, F., 1938. Allgemeines Lexikon der Bildenden Künstler von der Antike bis zur Gegenwart, Band 32: Stephens-Theodotos. E. A. Seemann. - Leipzig.

Bibliothèque nationale de France. Cabinet des Estampes. - Vc. 350. - 4. $\mathrm{K}-\mathrm{O}$.

Bibliothèque nationale de France. Département des estampes et de la photographie. Cabinet des Estampes. - Vc. 350. T. 7.

Bibliotheque nationale de France. Paris. Pierre Ricaud de Tirregaille. Palais de Cracoviec apparteneant a m. le Cte. Cettner du Cote de l'Entree. - Sign. - R 14550.

Bogdanowski, J., 2000. Polskie ogrody ozdobne. Warszawa: Arkady.

Ciołek, G. i Plapis, W., 1968. Materiały do słownika twórców ogrodów polskich. Warszawa.

Ciołek, G., 1954. Ogrody polskie. Warszawa.

Ciołek. G., 1955. Zarys historii kompozycji ogrodowej w Polsce. Łodz-Warszawa.

Czernecki, J., 1939. Mały król na Rusi i jego stolica Krystynopol. Kraków.

Hornung, Z., 1959. Na śladach działalności artystów francuskich w Polsce. Teka Kom. Hist. Sztuki. T.1.

Kosacka, D., 1970. Plany Warszawy XVII i XVIII w. w zbiorach polskich. Katalog. Warszawa. 
Kowalczyk, J., 1977, «Goût français» po warszawsku. Warszawskie pałace rokokowe na planie Ricaud de Tirregaille'a. Architektura, R. 31. Nr. 1-2.

Kowalczyk, J., 1981. Wędrówka po pałacach rokokowych z panem Ricaud. Jesteśmy w Warszawie. Miasto dawne i nowe. T. 1. Warszawa: PIW.

Kowalczyk, J., 1988, Pierre Ricaud de Tirregaille — architekt ogrodów i pałaców. Kwartalnik Architektury i Urbanistyki, 33. Z. 4.

Kowalczyk, J., 1988-1989. Ricaud de Tirregaille Pierre. Polski Słownik Biograficzny, T. XXXI. Wrocław - Warszawa - Kraków - Gdańsk - Łódź : Zakład Narodowy Imienia Ossolińskich, Wydawnictwo Polskiej Akademii Nauk,.

Kriegsarchiv des Österreichischen Staatsarchivs in Wien., 1763-1787. Josephinische Landesaufnahme, - B IX a 390.

Łoza, S., 1931. Architekci i budowniczowie w Polsce. Stownik architektów i budowniczych Polaków oraz cudzoziemców w Polsce pracujacych. Wydanie drugie, uzupelnione. Warszawa: Wydawnictwo Kasy im. Mianowskiego, Instytutu Popierania nauki, Palac Staszica.

Majdecki, L., 2008. Historia Ogrodów. T. 1: Od starożytności po Barok. Warszawa: Wydawnictwo naukowe PNW, s.419-420.

Mańkowski, T., 1932. Lwowskie kościoły barokowe. Prace sekcyi historyi sztuki i kultury Towarzystwa Nauk we Lwowie, T. 2, Zesz. 2.

Mańkowski, T., 1948. Architekt Pierre Ricaud de Tirregaille. Rocznik Zakładu Narodowego im. Ossolińskich. T. 3.

Morelowski, M., 1959. Pierre Ricaud de Tirregaille. Francastel P. Les architectes célèbres. T. II.

Narodowy Instytut Dziedzictwa w Warszawie (Ośrodek Dokumentacji Zabytków w Warszawie). - Текі Jana Glinki.

Olszewicz, B., 1932. Kartografia polska XVIII wieku. Polski Przegl. Kartogr. - R. 10: Nr. 38-39.

Ricaud de Tirregaille, P., 1867. Encyklopedyja powszechna, T.25. Warszawa.

Ross, J., 1970. Pałacyk w Perespie. Rokoko. Studia nad sztuka 1 połowy XVIII w. Warszawa.

Świeykowski, E., 1907-1912. Plany zamku Franciszka Salezego Potockiego wojewody kijowskiego w Krystynopolu nad Bugiem w powiecie sokalskim. Spraw. Kom. do Badań Hist. Sztuki w Polsce, T.8, Kraków.

Wątroba, P., 2016. Le palais d'Ignacy Cetner a Krakowiec Et son architecte Pierre Ricaud de Tirregaille nouvelles constatations et hypotheses. Studia z historii sztuki ofiarowane profesorowi Janowi Ostrowskiemu. Kraków, 2016.

Żyłko, E., 1955. Mecenat artystyczny Jana Klemensa Branickiego hetmana wielkiego koronnego. Warszawa.

\section{References}

Hrynyk, H. and Yarosh-Zamoys'ka, O., 2000. Krystynopil' (1692-1951). Chervonohrad.

Koval'chyk, YE., 1991. Late Baroque magnate residences in Volyn and Lviv region. Ukrayins'ke baroko ta yevropeys'kyy kontekst. Kyyiv : Naukova dumka.

Vuytsyk, V. S., 2003. Lviv baroque palaces. Palats Bil's'kykh. Visnyk instytutu «Ukrzakhidproektrestavratsiya», 13. 


\title{
THE CREATIVE WORK OF ARCHITECTOR PIERRE RICAUD DE TIRREGAILLE
}

\author{
(C) Taras V. Ya., 2020.
}

Abstact: In this article we examine the figure of the military engineer, geometer, architect Pierre Rico de Tirregaille (Tirrgaille, French Pierre Ricaud de Tirregaille, Ricaud (Ricaut, Ryko) Pierre de Tirregaille (Tirgaille)). The years of his activity (about 1725 - after 1772) are relatively well known to researchers. But his biography remains unknown, except for the period of activity in the Commonwealth. Analysis of the results of previous research has shown that scientific research has been conducted in several areas. The first area includes research on biographical information about the architect. The second area includes studies on various projects that Pierre Rico de Tirregail commissioned. Manuscripts and graphics are important sources for finding out about Pierre Rico de Tirregail and his design work. They are stored in the archives of Warsaw, Krakow, the National Heritage Institute in Warsaw and the National Library of France in Paris.

Pierre Ricaud de Tirregaille was born around 1725 in a French noble family in the district of Tiregale in Provence. His professional education was improved in Barcelona under the guidance of engineer Francis Ricode de Tierreagil. In the territory of the PolishLithuanian Commonwealth he worked from 1752 to 1762. We distinguish three periods in the activity of the architect: I - Warsaw (1752-1757), II - Lviv (1757-1760) and III Warsaw (1760-1762). Most orders were received by the architect from several magnate families: Branicki, Potocki, Mniszeck, and others. The first mention of Pierre Rico de Tirregail's stay in the Polish-Lithuanian Commonwealth dates back to 1752, when he received the rank of lieutenant in the infantry regiment of the Grand Crown Hetman Jan Kliment Branicki (1689-1771). In the architect's portfolio were included: the project and management of installation works on the water supply of the garden and menagerie in the city of Bialystok, the project of the palace with a garden in the city of Krystynopol, the palace in the village Pespa, a project of the Palace Chatsky-Felinsky in Lviv, a project for the modernization of the palace for Anthony Bielsky. Probably, the palace garden for the Greek Catholic Metropolitans in Lviv and the palace with a garden in Krakovets are his work as well. Pierre Ricaud de Tirregaille also made a detailed plan of the city of Warsaw on a scale of 1:1000 between 1762-1763. After an eleven-year stay in Poland, Pierre Rico de Tirregail moved to Berlin. In Berlin, he received a position in the military engineering corps and a position as a teacher at the court of King Frederick II of Prussia. In 1772, in Potsdam, he published a numismatic treatise devoted to Rossian medals of the eighteenth century.

Keywords: architect, Pierre Ricaud de Tirregaille, palace, garden, hydrosystems. 